\title{
Risk Factors of Diabetic Foot in Type 2 Diabetic Patients, Menoufia University Hospital, Egypt.
}

\author{
Aml A. Salama ${ }^{1}$ and Shimaa Kamal Zorin ${ }^{1}$ \\ ${ }^{1}$ Faculty of medicine, Menoufia University, Egypt.
}

Received: April, 2017 Accepted: June, 2017

\begin{abstract}
Background: Diabetic foot is a serious disabling complication of type 2 diabetes mellitus as it may lead to unhealed injuries in lower limb and impending amputation. Identifying its risk factors is an important step for prevention. Objective: To identify the risk factors of diabetic foot among type 2 diabetic patients. Method: This is a case control study of random sample of 60 diabetic foot patients (cases) and 420 diabetic patients without foot lesion (control), selected from patients attending Family medicine, Internal medicine, Endocrinology and Diabetic foot outpatient clinics; Menoufia University hospitals. The patients were interviewed using predesigned questionnaire inquired about personal and present history items. Fasting, two hours postprandial blood glucose and $\mathrm{HbAlc}$ were done as a part of routine diabetic investigations. Results: Independent risk factors by logistic regression were age more than 50 $(\mathrm{OR}=4.04 ; 95 \%$ CI $2.41-8.17 ; \mathrm{p}<0.001)$, urban residence which was protective $(\mathrm{OR}=0.09$; $95 \%$ CI $0.028-0.285 ; \mathrm{p}<0.001)$, low socioeconomic standard $(\mathrm{OR}=2.22 ; 95 \%$ CI $1.074-$ 4.595; $\mathrm{p}=0.031)$, hyperlipidmia $(\mathrm{OR}=4.72 ; 95 \%$ CI $1.597-7.285 ; \mathrm{p}=0.005)$, obese patients $(\mathrm{OR}=2.26 ; 95 \%$ CI $1.09-4.73 ; \mathrm{p}=0.029), \quad$ hypertension $\quad(\mathrm{OR}=7.21 ; 95 \% \mathrm{CI} 2.29-$ $14.63 ; \mathrm{p}=0.001)$ and absence of neuropathy $(\mathrm{OR}=0.02 ; 95 \%$ CI $0.008-0.076 ; \mathrm{p}<0.001)$. Conclusion: Age more than 50; rural residence, low socioeconomic standard, hyperlipdemia, obesity, hypertension and neuropathy were identified as risk factors for diabetic foot in the studied type 2 diabetes patients. Determining these risk factors for individual patients is an important step for prevention of disability and reduction of the cost of hospitalization..
\end{abstract}

Key words: Risk Factors, Diabetic foot, Type 2 diabetes mellitus

Corresponding Author: Dr. Aml Ahmed Salama

E mail : aml_salama2002@yahoo.com

\section{Introduction}

Although being preventable, diabetic foot is a common complication of diabetes, resulting into sever insult to patient's life as a result of possible amputation at it's the end stages. According to Centers for Disease Control and Prevention (CDC), 2013 "Egypt is among 10 top countries with the highest prevalence of diabetes, among those diabetic patients up to $15 \%$ will develop foot complication in their lifetime". ${ }^{1}$
Diabetic foot is a group of syndromes in which neuropathy, ischemia and infection leads to tissue breakdown resulting in morbidity and possible amputation. ${ }^{2}$ Uncontrolled diabetes and peripheral neuropathy were reported as its main risk factors. ${ }^{3}$ The diabetic foot may started as simple as minor trauma, impeded toe nail, dryness and inter-digital infections proceeded to ulceration, severe infection, gangrene and amputation. ${ }^{4}$ 
Dealing with preventable risk factors will reduce the cost of hospitalization and management for cases with diabetic foot but this requires first identification of this risk factors and determine it for each patient. $^{5}$ The role of family physician in close follow up for diabetic patients to reduce impact of risk factors and strengthen protective factors through primary and screening asymptomatic patients through secondary prevention may be the corner stone for elimination of this serious complication. ${ }^{6}$

According to National Egyptian Guidelines for Family Physicians 7 , Family physician should educate diabetic patient, simple maneuvers as daily foot inspection, dry after washing, proper cutting of the nails, avoid tight or exposed shoes and use moisturizing agents to avoid dryness.

During monthly follow up visit, foot should be thoroughly examined, with early detection of manifestations of ischemia and neuropathy with tight control of blood glucose level, blood pressure and blood lipids. ${ }^{8}$

\section{Method}

Study design and setting: A case control study was conducted in outpatient clinics of Family Medicine, Internal Medicine, Endocrinology and Diabetic foot, Menoufia University Hospital over a period of three months (From the beginning of December 2016 to the end of February, 2017). Cases were matched with control regarding their socio-demographic characteristics. Study subject and sampling: The study subjects included type 2 diabetic patients attending Family Medicine , Internal Medicine and Endocrinology outpatients clinics for routine follow up. Diabetic foot cases were referred from the previous three clinics to diabetic foot clinic (one day /week clinic) According to the flow rate of diabetic patients at the three clinics in the prior three months to the study which was about 1200 cases of diabetes and about 150 case of diabetic foot . Using Epi Info program, (Atlanta, Georgia, USA) at $95 \%$ confidence interval and power 80 ,the sample size was calculated to be 57 for diabetic foot cases and 400 for control group which was increased to 60 cases and 420 cases to avoid dropping out and / or refusal to participate.

The required sample was collected randomly 2 days / week in each clinic, in a period of three months. The study sample consisted of 480 type 2 diabetic patients; 60 diabetic patients ( who had at least one episode of any type of diabetic foot as ulcer, infections, unhealed wound, gangrene or previous amputation during the course of their disease were included as 'cases' and other 420 controls (type 2 diabetic without history or current diabetic foot collected at family medicine, and endocrinology outpatients clinic ).

The inclusion criteria for cases was all type 2 diabetic patients, both gender, with history diabetic foot admitted to the previous mentioned clinics or current diabetic foot admitted to diabetic foot clinic at the hospital; while that for controls was type 2 diabetic patients, both gender without diabetic foot . Patients with other causes of neuropathy were excluded. Both groups were matched for age and gender.

\section{Data collection:}

Filling predesigned questionnaire sheet through direct interview with the patients.

The questionnaire covers history items : including age, sex, Socioeconomic standard which was assessed through their education, occupation, income, number of individual per room, type of housing, material possessions, etc.....), they graded into high ,middle and low socioeconomic status. ${ }^{9}$ Smoking, duration of diabetes and 
its current management (i.e. oral hypoglycemic agents, insulin, or both), follow diet regimen were also assessed. Co-morbidites of diabetes were also assessed as hypertension and hyperlipidemia (or on lipid-lowering medications). Diabetic complications as cardiac diseases were also assessed.

Foot self-care was assessed through direct questions regarding foot care practice as: washing foot everyday by soap and water, dry foot after wash, daily foot inspection for wound and infection and the way of cutting the toe nail (by direct observation of upper edge of toenail, straight edges is the right way of cutting toenails while curved edge is wrong).

Validation of the questionnaire was done through its submission to a panel of 4 expertise to test its validity .The expertise were professors of internal medicine, family medicine and two endocrinologists. The items were revised by the expertise to determine whether the items were relevant for assessment.

The expertise were asked to evaluate individual items in relation to its relevance and appropriateness and rate items on a 4 point scale : score 4 for Adequate (simple, relevant \& clear item), 3 for adequate but needs minor modification, 2 for items needs major modification, 1 for not so adequate (can be omitted). Content validity index (CVI): percentage of total item rated by expertise as either 3 or 4 .

The score of $\geq 80 \%$ is generally considered to have a good validity. CVI of the designed questionnaires was $85 \%$.

Physical examination: Height in centimeters was measured bare footed with the patients standing straight. Weight in kilograms was recorded using portable weighting scale with patient bare footed standing straight with heel together while wearing light clothes. Body mass index Table (1): Comparison of diabetic foot cases and control regarding their demographic criteria
(BMI) is calculated for each patient as formula: weight $(\mathrm{kg}) /$ [height $\left.\left(\mathrm{m}^{2}\right)\right]$.

Blood pressure (BP) was measured using a suitable mercury sphygmomanometer after a 10 minutes rest with the patient in the sitting position and cubital fossa at heart level. BP was measured two times at 5 minutes interval. Hypertension was defined as a systolic blood pressure $\geq 140$ $\mathrm{mmHg}$ and/or a diastolic blood pressure $\geq$ 90 mmHg. ${ }^{10}$ The participants currently using antihypertensive medications were also classified as positive for hypertension even if they had normal blood pressure.

All patients underwent a detailed foot examination to identify previous lowerlimb amputations, below the ankle infections including inter-digital infections and presence of any sore, a wound or ulcers. Signs of infection (swelling, exudates, surrounding cellulitis, odor and tissue destruction or necrosis).

Neurological examination was done through ten grams monofilament (touch), Neuro-tip (pain) and by $128 \mathrm{~Hz}$ tuning fork over the foot bony prominence (vibration). The patients was considered having neuropathy by loss of vibration sense or pain or less than 8 point in the $10 \mathrm{gm}$. monofilament. The presence of pulse was assessed on dorsal pedis and tibial posterior arteries. Peripheral arterial diseases were assessed through abnormal skin color, poor hair growth and cold skin.

Ischemic Heart Disease was assessed based on the history of hospital admission for either myocardial infarction (MI) or angina, positive ECG for prior $\mathrm{MI}$ or angina and positive history of coronary artery bypass grafting or percutaneous transluminal coronary angioplasty.

Laboratory analysis: Subjects were asked to fasting 6 to 8 hours overnight (no caloric intake). The fasting venous blood 


\begin{tabular}{|c|c|c|c|c|c|c|c|}
\hline $\begin{array}{l}\text { Demographic } \\
\text { character }\end{array}$ & $\begin{array}{c}\text { Cases } \\
(\mathrm{N}=60) \\
\mathrm{N}(\%) \\
\end{array}$ & $\begin{array}{c}\text { Control } \\
(\mathrm{N}=420) \\
\mathrm{N}(\%)\end{array}$ & $\begin{array}{c}\text { Total } \\
(\mathrm{N}=480) \\
\mathrm{N}(\%) \\
\end{array}$ & $\begin{array}{c}\mathrm{X}^{2} \\
\text { Test }\end{array}$ & $\begin{array}{c}P \\
\text { value }\end{array}$ & $\begin{array}{l}\text { Odds } \\
\text { Ratio }\end{array}$ & $\begin{array}{c}\text { CI } \\
(95 \%)\end{array}$ \\
\hline $\begin{array}{l}\text { Sex } \\
\text { - Male } \\
\text { - Female* }\end{array}$ & $\begin{array}{l}34(56.7) \\
26(43.3)\end{array}$ & $\begin{array}{l}117(26.9) \\
303(72.1)\end{array}$ & $\begin{array}{l}151(31.5) \\
329(68.5) \\
\end{array}$ & 20.3 & $<0.001$ & 0.295 & $0.17-0.514$ \\
\hline $\begin{array}{l}\text { Age of patients } \\
\text { Mean } \pm \text { SD } \\
\end{array}$ & $56.47 \pm 7.42$ & $51.2 \pm 12.48$ & $51.86 \pm 12.05$ & $3.18^{* *}$ & 0.002 & ------- & - \\
\hline $\begin{array}{l}\text { Residence } \\
\text { - Rural } \\
\text { - Urban* }\end{array}$ & $\begin{array}{l}48(80) \\
12(20) \\
\end{array}$ & $\begin{array}{l}199(47.4) \\
221(52.6) \\
\end{array}$ & $\begin{array}{l}247(51.5) \\
233(48.5) \\
\end{array}$ & 22.4 & $<0.001$ & 0.225 & $0.116-0.436$ \\
\hline $\begin{array}{l}\text { Patient Education } \\
\text { - Illiterate * } \\
\text { - Read and write } \\
\text { - Basic } \\
\text { - Secondary } \\
\text { - High } \\
\end{array}$ & $\begin{array}{r}28(46.7) \\
21(20) \\
7(11.7) \\
8(13.3) \\
5(8.5) \\
\end{array}$ & $\begin{array}{r}181(43.1) \\
72(17.1) \\
38(9) \\
33(7.9) \\
96(22.9) \\
\end{array}$ & $\begin{array}{r}209(43.5) \\
84(17.5) \\
45(9.4) \\
41(8.5) \\
101(21) \\
\end{array}$ & 7.88 & 0.096 & $\begin{array}{l}------ \\
0.531 \\
0.839 \\
0.638 \\
2.970\end{array}$ & $\begin{array}{l}-0.238-0.994 \\
0.342-2.064 \\
0.268-1.521 \\
1.111-6.232\end{array}$ \\
\hline $\begin{array}{l}\text { Socioeconomic } \\
\text { - Low* } \\
\text { - Middle } \\
\text { - High } \\
\end{array}$ & $\begin{array}{l}35(59.3) \\
15(25.4) \\
10(16.3) \\
\end{array}$ & $\begin{array}{r}328(78.1) \\
52(12.4) \\
40(9.5) \\
\end{array}$ & $\begin{array}{r}363(75.8) \\
67(14) \\
50(11.2) \\
\end{array}$ & 10.36 & 0.006 & $\begin{array}{l}------- \\
0.369 \\
0.427 \\
\end{array}$ & $\begin{array}{c}0.188-0.724 \\
0.196-0.927\end{array}$ \\
\hline
\end{tabular}

* Reference Group, ** t test

sample was taken by the laboratory technician and fasting blood sugar level measured by RA 50 analyzer, wave length 505 , using spin-react regain. 2 hour postprandial glucose level values were assessed after two hours of receiving an ordinary breakfast. ${ }^{11}$

\section{Statistical Analysis:}

Data were analyzed with the Statistical Package for the Social Sciences (SPSS) v.21 for Windows (IBM Inc. Chicago, IL), and the results were considered statistically significant when $\mathrm{p}<0.05$. For quantitative data analysis. Simple frequencies were used for data checking.

Quantitative data was expressed as mean and standard deviation $(\mathrm{X} \pm \mathrm{SD})$ and analyzed by Student t- test for comparison of two groups of normally distributed variables.

Qualitative data was expressed as number and percentage and analyzed by Chisquare test. A logistic regression model was constructed in order to estimate odds ratios (Confidence Interval 95\%) for the presence of diabetic foot, adjusted by the following significant parameters with specific reference for each : age more than fifty years, male sex, illiterate, urban residency, low socioeconomic status, wash and dry foot every day, hypertension by history or on medication, hyper-lipidemia from history or on medication , smoking, less than five years of diabetic duration, obese patients, absence of neuropathy and $\mathrm{Hb} \mathrm{A} 1 \mathrm{c}>7.5 \mathrm{mg} / \mathrm{dl}$.

\section{Ethical Approval:}

The study was approved by the Ethical Committee of the Faculty of Medicine, Menoufia University. Administrative permissions were obtained from authority Menoufia University Hospital. Informed consent was signed by all participants after simple and clear explanation of the research objectives and procedure with assurance regarding the confidentiality of the obtained information.

\section{Results:}

The total study sample was 480 type 2 diabetic patients, the cases of diabetic foot as a complication of diabetes, were 60 while diabetic patient with no diabetic foot were 420 cases. Male sex was significantly

Table (2): Comparison of diabetic foot cases and control regarding their clinical characters 


\begin{tabular}{|c|c|c|c|c|c|c|c|}
\hline $\begin{array}{l}\text { Clinical } \\
\text { Character }\end{array}$ & $\begin{array}{l}\text { Cases } \\
(\mathrm{N}=60) \\
\mathrm{N}(\%)\end{array}$ & $\begin{array}{c}\text { Control } \\
(\mathrm{N}=420) \\
\mathrm{N}(\%)\end{array}$ & $\begin{array}{c}\text { Total } \\
(\mathbf{N}=480) \\
\mathbf{N}(\%)\end{array}$ & $\begin{array}{c}\mathrm{X}^{2} \\
\text { Test }\end{array}$ & $\begin{array}{c}P \\
\text { value }\end{array}$ & $\begin{array}{l}\text { Odds } \\
\text { Ratio }\end{array}$ & $\begin{array}{c}\text { CI } \\
(95 \%)\end{array}$ \\
\hline $\begin{array}{l}\text { Smoking } \\
\text { - Yes } \\
\text { - No* }\end{array}$ & $\begin{array}{l}20(33.3) \\
40(66.7)\end{array}$ & $\begin{array}{r}81(19.3) \\
339(80.7)\end{array}$ & $\begin{array}{l}101(21) \\
329(79)\end{array}$ & 6.236 & 0.013 & 0.478 & $0.265-0.861$ \\
\hline $\begin{array}{l}\text { Duration of DM } \\
\cdot<5 \text { years } \\
\cdot \geq 5 \text { years } \\
\end{array}$ & $\begin{array}{l}15(25) \\
45(75)\end{array}$ & $\begin{array}{l}175(41.7) \\
245(58.3)\end{array}$ & $\begin{array}{l}190(39.6) \\
290(60.4)\end{array}$ & 6.098 & 0.009 & 2.143 & $1.16-3.966$ \\
\hline $\begin{array}{l}\text { Treatment of DM } \\
\text { - Insulin } \\
\text { - Oral * } \\
\end{array}$ & $\begin{array}{l}43(71.7) \\
17(28.8) \\
\end{array}$ & $\begin{array}{l}124(29.5) \\
296(70.5)\end{array}$ & $\begin{array}{l}167(34.8) \\
313(65.2) \\
\end{array}$ & 41.09 & $<0.001$ & 1.66 & $0.091-0.302$ \\
\hline $\begin{array}{l}\text { Neuropathy } \\
\text { - Yes } \\
\text { - No* }\end{array}$ & $\begin{array}{l}45(75) \\
15(25)\end{array}$ & $\begin{array}{r}61(14.5) \\
359(85.5) \\
\end{array}$ & $\begin{array}{l}106(22.1) \\
374(77.9)\end{array}$ & $15.09^{\mathrm{F}}$ & $<0.001$ & 0.435 & $0.116-0.836$ \\
\hline $\begin{array}{l}\text { Hypertension } \\
\text { - Yes } \\
\text { - No* }\end{array}$ & $\begin{array}{l}19(31.7) \\
41(68.3) \\
\end{array}$ & $\begin{array}{l}163(38.8) \\
257(61.2) \\
\end{array}$ & $\begin{array}{l}182(37.9) \\
298(62.1)\end{array}$ & 1.138 & 0.321 & 1.369 & $0.768-2.438$ \\
\hline $\begin{array}{l}\text { IHD } \\
\text { - Yes } \\
\text { - No* }\end{array}$ & $\begin{array}{r}7(11.7) \\
53(88.3) \\
\end{array}$ & $\begin{array}{r}65(15.5) \\
355(84.5) \\
\end{array}$ & $\begin{array}{r}72(15) \\
408(85) \\
\end{array}$ & $1.598^{\mathrm{F}}$ & 0.289 & 1.386 & $0.604-3.184$ \\
\hline $\begin{array}{l}\text { Hyperlipidemia } \\
\text { - Yes } \\
\text { - No* }\end{array}$ & $\begin{array}{l}11(18.3) \\
49(81.7) \\
\end{array}$ & $\begin{array}{l}128(30.5) \\
292(69.5)\end{array}$ & $\begin{array}{l}139(29) \\
341(71)\end{array}$ & $3.763^{\mathrm{F}}$ & 0.067 & 1.953 & $0.983-3.878$ \\
\hline
\end{tabular}

IHD : Ischemic Heart Disease, ${ }^{*}$ Reference Group ${ }^{F}$ Fisher Exact

higher among cases $(56.7 \%)$ than control group $(26.9 \%),(\mathrm{OR}=0.295$; 95\% CI 0.17 $0.514 ; \mathrm{p}$ value $<0.001)$. Age constituted statistical significant difference and risk factor between cases and control groups, as the mean of age of diabetic foot patients was higher than that of the control group $(56.47 \pm 7.42$ versus $51.2 \pm 12.48 ; \mathrm{p}$ $=0.002)$. Most of cases $(80 \%)$ were rural areas inhabitants. The residence constituted statistical significant difference between cases and control $[\mathrm{OR}=0.225$; $\% 95$ CI 0.116 - 0.436; p value $<0.001$,). Socioeconomic stander constituted statistical significant difference between cases and control with higher ratio of low stander (reference group) was among control group $(\mathrm{p}=0.006)$ (Table 1).

Some items in the clinical history of the patient constituted statistical significant difference between cases and control as smoking $(\mathrm{OR}=0.478, \% 95$; CI 0.265-0.861; $\mathrm{p}$ value $=0.013)$, long duration of diabetes (more than five years) $(\mathrm{OR}=2.143, \% 95 ; \mathrm{CI}$ 1.16-3.966;p value=0.009), type of diabetes treatment $(\mathrm{OR}=1.66, \% 95 ; \mathrm{CI}$ $0.091-0.302 ; p$ value $<0.001)$ and presence of neuropathy $(\mathrm{OR}=0.435, \% 95$; CI0.1160.836 ; $p$ value $<0.001)$. Present history of hypertension, hyperlipidemia or ischemic heart disease didn't constitute statistical significant difference between groups (Table 2).

Regarding self care practice to safeguard diabetic foot, daily foot wash using warm water and soap was done in higher percentage of control than cases (35\% versus $15 \%$ respectively ), this difference was statistically significant $(\mathrm{OR}=0.328$, $\% 95 ;$ CI $0.157-0.684$; p value $=0.002$ ) . Drying foot after washing was done by $31.9 \%$ of control compared by $15 \%$ of cases, this difference was statistically significant between groups $(\mathrm{OR}=0.377, \% 95 ; \mathrm{CI} 0.18-0.788 ; \mathrm{p}$ value $=$ 0.004). Daily foot inspection and method of cutting toenails didn't constitute 
Table (3): Comparison of diabetic foot cases and control regarding their daily Foot care practice characters:

\begin{tabular}{|c|c|c|c|c|c|c|c|}
\hline $\begin{array}{l}\text { Daily Self Care } \\
\text { Foot Parameters }\end{array}$ & $\begin{array}{c}\text { Cases } \\
(\mathrm{N}=60) \\
\mathrm{N}(\%)\end{array}$ & $\begin{array}{c}\text { Control } \\
(\mathrm{N}=420) \\
\mathrm{N}(\%)\end{array}$ & $\begin{array}{c}\text { Total } \\
(\mathrm{N}=480) \\
\mathrm{N}(\%)\end{array}$ & $\begin{array}{c}\mathbf{X}^{2} \\
\text { Test }\end{array}$ & $\begin{array}{c}P \\
\text { value }\end{array}$ & $\begin{array}{l}\text { Odds } \\
\text { Ratio }\end{array}$ & $\begin{array}{c}\text { CI } \\
(95 \%)\end{array}$ \\
\hline $\begin{array}{l}\text { Daily Foot Wash } \\
\text { - Yes } \\
\text { - } \mathrm{No}^{*}\end{array}$ & $\begin{array}{r}9(15) \\
51(85)\end{array}$ & $\begin{array}{l}147(35) \\
273(65)\end{array}$ & $\begin{array}{l}342(67.5) \\
156(32.5)\end{array}$ & $9.573^{\mathrm{F}}$ & 0.002 & 0.328 & $0.157-0.684$ \\
\hline $\begin{array}{l}\text { Dry foot after } \\
\text { wash } \\
\text { - Yes } \\
\text { - } \mathrm{No}^{*} \\
\end{array}$ & $\begin{array}{r}9(15) \\
51(85)\end{array}$ & $\begin{array}{l}134(31.9) \\
286(68.1)\end{array}$ & $\begin{array}{l}143(29.8) \\
337(70.2)\end{array}$ & $7.173^{\mathrm{F}}$ & 0.004 & 0.377 & $0.18-0.788$ \\
\hline $\begin{array}{l}\text { Daily Foot } \\
\text { inspection } \\
\text { - Yes } \\
\text { - No* } \\
\end{array}$ & $\begin{array}{l}12(20) \\
48(80)\end{array}$ & $\begin{array}{l}127(30.2) \\
293(69.8) \\
\end{array}$ & $\begin{array}{l}139(29) \\
341(71)\end{array}$ & 2.675 & 0.102 & 0.577 & $0.296-1.123$ \\
\hline $\begin{array}{l}\text { Cutting toenail } \\
\text { - Curved (wrong ) } \\
\text { - Straight (right) }\end{array}$ & $\begin{array}{l}27(45) \\
33(55)\end{array}$ & $\begin{array}{l}136(32.4) \\
284(67.6)\end{array}$ & $\begin{array}{l}163(34) \\
317(66)\end{array}$ & 3.728 & 0.054 & 1.709 & $0.899-2.956$ \\
\hline
\end{tabular}

* Reference group, ${ }^{F}$ Fisher Exact Test

statistical significant difference between groups (Table 3).

Comparing the mean of $\mathrm{BMI} \pm \mathrm{SD}$ among groups, it was significantly higher in diabetic foot group $(36.69 \pm 8.63)$ than control group (33.78 \pm 9.12$)$ with $p=0.02$. Mean \pm SD of systolic blood pressure showed no statistical significant difference between groups while mean \pm SD of diastolic blood pressure was significantly higher among diabetic foot group $(88.66 \pm 10.07)$ than control group (85.07 \pm 11.57$), \mathrm{p}=0.023$ (Table 4).

Regarding investigation of blood glucose level, mean \pm SD of fasting blood glucose level was statistical significantly higher among cases of diabetic foot than that of the control group $(198.8 \pm 38.74$ versus $180.55 \pm 39.44, p=0.001)$. HGA1c was statistically significantly higher among cases than control group (10.89 \pm 2.54 versus $10.21 \pm 2.48, \mathrm{p}=0.047)$, which indicated uncontrolled blood glucose over that prior three months in the diabetic foot group. Two hour postprandial blood glucose showed no statistical significant difference among groups (Table 3).

To identify risk factors that were independently associated with diabetic foot and to control confounders, significant risk factors were analyze into logistic regression model . the risk factors which remained independently significant to the risk of diabetic foot were age more than 50 $(\mathrm{OR}=4.04 ; 95 \%$ CI $2.41-8.17$; $<<0.001)$, urban residence which was protective $(\mathrm{OR}=0.09 ; 95 \%$ CI $0.028-\quad 0.285$; $\mathrm{p}<0.001)$, low socioeconomic stander $(\mathrm{OR}=2.22$; $95 \%$ CI $1.074-4.595$;

$\mathrm{p}=0.031)$, hyperlipidmia $(\mathrm{OR}=4.72 ; 95 \%$ CI 1.597 -

$7.285 ; \mathrm{p}=0.005), \quad$ obese patients $(\mathrm{OR}=2.26 ; 95 \%$ CI $1.09-4.73 ; \mathrm{p}=0.029)$, Hypertensive patients $(\mathrm{OR}=7.21 ; 95 \%$ CI $2.29-14.63 ; \mathrm{p}=0.001)$ and absence of neuropathy was also protective $\quad(\mathrm{OR}=0.02 ; 95 \%$ CI $0.008-$ $0.076 ; \mathrm{p}<0.001)$ (Table 5).

\section{Discussion:}

The aim of this study was to assess risk factors of diabetic foot as a serious complication of diabetes, as a step contributing to establish preventive measures for this disabling complication through handling of its modifiable risk factors . 
Table (4): Comparison of diabetic foot cases and control regarding their body mass index, blood pressure and blood glucose level

\begin{tabular}{lcccc}
\multicolumn{1}{c}{ Parameters } & $\begin{array}{c}\text { Cases } \\
(\mathbf{N}=\mathbf{6 0}) \\
\text { Mean } \pm \text { SD }\end{array}$ & $\begin{array}{c}\text { Control } \\
(\mathbf{N = 4 2 0}) \\
\text { Mean } \pm \boldsymbol{S D}\end{array}$ & t test & $\begin{array}{c}\text { P } \\
\text { value }\end{array}$ \\
\hline Body mass index & $36.69 \pm 8.63$ & $33.78 \pm 9.12$ & -2.330 & 0.02 \\
Systolic BP & $132.33 \pm 15.55$ & $131.71 \pm 18.9$ & -0.242 & 0.81 \\
Diastolic BP & $88.66 \pm 10.07$ & $85.07 \pm 11.57$ & -2.286 & 0.02 \\
\hline Blood Glucose Level & & & & \\
- Fasting BG & $198.8 \pm 38.74$ & $180.55 \pm 39.44$ & -3.358 & 0.001 \\
- 2h postprandial & $239.6 \pm 56.36$ & $223.9 \pm 59.92$ & -1.911 & 0.057 \\
- HbA1c & $10.89 \pm 2.54$ & $10.21 \pm 2.48$ & -1.963 & 0.047 \\
\hline
\end{tabular}

In the current study, male sex was significantly higher among cases $(56.7 \%)$ than control group $(26.9 \%)$. This may be contributed to the additional risk of male sex to cardiovascular events and being more prone to trauma. Another factor is that smoking which is more common among males in our Arab communities carries an additional risk of all cardiovascular complication. Simon et al.(1999) $)^{12}$, reported 1.4 fold increase in the prevalence of all diabetic complications among men comparing to woman, while other studies ${ }^{13,14}$ reported effect of male sex on occurrence of diabetic foot in diabetic patients. In contrast, some other studies ${ }^{15,16}$ found no difference in the prevalence of diabetic foot among male and female patients.

The mean of age in diabetic foot patients was statistically significantly higher than that of the control group. This may be contributed to decease level of foot care with aging. Al-Maskari et al.(2007) ${ }^{13}$, reported increase prevalence of neuropathy due to aging as a combined risk factor of diabetic foot in diabetic patients. The Same finding was approved in many studies ${ }^{15,17}$ while other studies reported no effect of age on occurrence of diabetic foot. ${ }^{18,19}$

Rural residence was significantly higher in diabetic foot group than control group ( $80 \%$ of cases were inhabitants of rural areas). This is may be due to poor sanitation in the countryside of Egypt with prevalent habit of wearing exposed slippers or walking bare foot. Another study which was done in Gaza, Palestine ${ }^{17}$, reported higher percent of diabetic foot patients $(56 \%)$ who lived in middle area of Gaza strip which is mainly composed of refugee camps with unhygienic living.

The current study showed that $59.3 \%$ of diabetic foot cases were among low socioeconomic stander, compared to $78.1 \%$ of the control group in that level. This indicted that type 2 diabetes and it's complication is higher among low socioeconomic standers. The same result was reported by Jayesh et al., 2012 ${ }^{15}$, who showed that more than half of the diabetic foot patients were from low socioeconomic class, $34 \%$ in the middle and $9 \%$ to the upper class. Other studies $20,21,22$ of social factors influences on foot infection mentioned that low socioeconomic is a proved risk factor for diabetic foot. Low socioeconomic stander hiders the ability to obtain medication and consultation services expenses that may improve health. ${ }^{23}$

In the current study smoking was statistical significantly higher among diabetic foot patients than control group (33\% versus 19 $\%$ respectively). This may contributed to the negative insult of smoking on cardiovascular system. Other studies 
Table (5): Logistic regression analysis of risk factors associated with diabetic foot in the studied group

\begin{tabular}{lrrrc}
\hline Risk Factor Parameters & (Beta) & P value & \multicolumn{1}{l}{$\begin{array}{l}\text { Odds } \\
\text { ratio }\end{array}$} & $\begin{array}{l}\text { Confidence Interval } \\
\text { Upper - Lower }\end{array}$ \\
\hline Age (> 50 years) & 2.675 & 0.001 & 4.04 & $2.41-8.17$ \\
Sex (female patient) & -0.834 & 0.086 & 0.434 & $0.168-1.125$ \\
Urban Residence & -2.41 & $<0.001$ & 0.09 & $0.028-0.285$ \\
Low Socioeconomic Standard & 0.798 & 0.031 & 2.22 & $1.074-4.595$ \\
Wash Foot Every Day & 1.206 & 0.187 & 3.341 & $0.556-20.06$ \\
Dry Foot Every Day & -2.191 & 0.14 & 0.112 & $0.02-0.639$ \\
Diastolic Hypertension & 1.975 & 0.001 & 7.201 & $2.298-22.603$ \\
Less than five years duration of & -0.444 & 0.402 & 0.641 & $0.227-1.812$ \\
$\quad$ DM & 0.069 & 0.901 & 1.071 & $0.363-3.162$ \\
Smoking & 0.818 & 0.029 & 2.266 & $1.085-4.731$ \\
Obese patients & -3.716 & $<0.001$ & 0.024 & $0.008-0.076$ \\
Absence of Neuropathy & 0.977 & 0.137 & 2.656 & $0.732-5.636$ \\
Hg A1c $>$ 7.5mg/dl & & $c 0 m p a r$ &
\end{tabular}

reported that smoking increases the risk of developing diabetic foot even if being exsmoker. ${ }^{17,21,24}$ In contrast some other studies found no association between smoking and the risk of amputation. ${ }^{25,26}$ Shailesh et al, 2012 27 , revealed that the presence of diabetic foot ulcer was higher among habitual smokers or who were smokers or tobacco users. Furthermore, smoker diabetic patients who are more prone to amputations compared to those who did not smoke, and that increase the number of smoking years follow an increasing trend of more amputations.

Long duration of diabetes ( $>$ five years ) was significantly higher in cases of diabetic foot than control group, this could be explained by longer diabetes duration may enforces the pathology of chronic complications, especially neuropathy. ${ }^{28}$

The positive and strong association between diabetes duration and risk of foot complications reported in other studies. ${ }^{29,30}$ A study ${ }^{31}$ confirmed that diabetes duration of $\geq 10$ years significantly increased the risk for foot ulceration and amputation by 3 to 4 folds.

The current study showed that $71.7 \%$ of diabetic cases were treated by insulin compared to $29.5 \%$ of control group before and at the time of occurrence of diabetic foot. This finding may be due to the need to add insulin if the blood glucose failed to be controlled by oral hypoglycemic or in case of complications as diabetic foot (33). Most patients couldn't determine exactly why insulin was added or when. So we can't rely that insulin is a risk to develop diabetic foot because it may be a result of uncontrolled blood glucose and occurrence of complications not a cause. Al-Rubeaan et al., $2015^{19}$, reported that insulin use had demonstrated a significant increased risk with OR more than 2 in all affected, foot ulcer, gangrene, and amputation cases.

The prevalence of neuropathy in the current diabetic foot sample was $71.7 \%$, which is higher than the prevalence reported in some previous studies, ranging between $37 \%$ and $57 \%$ 3,33,34, 35 but closer to other studies, with a prevalence between $70 \%$ and $80 \%{ }^{36,37}$ Some studies reported that peripheral neuropathy is one of the strongest predictor for occurrence of diabetic foot. ${ }^{19,38,39}$

History of hypertension, hyperlipidemia or ischemic heart disease didn't constitute statistical significant difference between groups . Nehring et al., 2014 ${ }^{14}$, reported 
no correlation of diabetic foot in population with hyperlipidaemia. Alex et al.,2010(32), reported that diabetic cases with hypertension seem to be protected against foot complication as most of patients with hypertension in their sample were on ACE inhibitors (Enalapril), which enhanced peripheral circulation. In contrast, Dòria $\mathrm{M}$ et al., 2016 ${ }^{3}$, reported that " $68.5 \%$ of diabetic foot patients had dyslipidaemia, and $84.8 \%$ of them had hypertension".

Regarding self-care practice for safeguarding against diabetic foot, daily foot wash by soap and warm water and dryness after washing were done by significantly higher control population than cases population .Daily foot inspection for early detection of any trauma or infection was neglected by most of cases and control with no significant in between. Cutting toenail in straight manner, to prevent ingrown toe nail was done by more than half of patients in cases and control group with no significant difference in between. The findings Some studies ${ }^{17,22,40}$ revealed that proper foot care activities as washing feet every day, examining feet regularly and drying well between toes were protective factors that decreases the risk of developing foot complications among diabetic patients .

Body mass index was significantly higher among cases than control. This Finding was supported by other studies ${ }^{14,41}$, which demonstrated that BMI (over $25 \mathrm{~kg} / \mathrm{m}^{2}$ ) is risk factors of diabetes and its complications, while others found no relation of $\mathrm{BMI}$ to the occurrence of diabetic foot. ${ }^{42,43}$

Fasting and HGA1c (Mean and SD) were statistically significantly higher among cases of diabetic foot than control group. This indicate that inadequate blood glucose control is a risk factor for aggravation of all diabetic complication especially chronic non-healing diabetic foot ulcer which is associated with elevated HbAlc $>7 \% .^{24,29,32,44}$ Studies conducted in Sudan and Iran mentioned that elevated HbAlc was the main risk factor for diabetic foot infections and ulceration. ${ }^{39,45}$ In Arab communities , they called diabetic foot by sweet foot, the name which rely on high blood glucose above the normal levels which in turn predispose to infections and ulceration. ${ }^{46}$

Logistic regression model was done to identify the risk factors which remained independently significant to foot. This prove that the risk of diabetic foot increased in patients with age more than 50, low socioeconomic stander, obese patients and hypertension, while the risk decreased in urban inhabitants, female patients, patients who dry foot after washing, less than five years duration of diabetes and in absence of neuropathy .

A study which was done in Poland, 2014 ${ }^{14}$, reported in its binomial logistic analysis models that the risk of diabetic foot in patients with type 2 diabetes was decreased by patient's age and presence of hyperlipidaemia. In contrast, male gender, diabetes duration, and increased BMI and waist circumference potentiate the risk of diabetic foot.

\section{Conclusion}

The study shows difference between diabetic foot patients and other patients who are not complicated with diabetic foot during their diabetes. Although age ,sex, duration of diabetes are non modifiable risk factors, other risk factors as diabetic control ,loss of weight, smoking and appropriate diabetic foot care could be modified by proper patient education conducted through his family physician during follow up visits, taking in consideration the possibility and the insult of diabetic foot disabilities 


\section{References:}

1. Centers for Disease Control and Prevention (CDC). National diabetes fact sheet: national estimates and general information on diabetes and pre-diabetes in the World and it's prevention. The diabetic foot examination: A positive step in the prevention of diabetic foot ulcers and amputation. Osteopathic Family Physician (2013) 5, 73-78.

2. World Health Organization. Definition and diagnosis of diabetes mellitus and intermediate hyperglycemia : report of a WHO/IDF consultation2006(pp1-46) Retrieved from http://whqlibdoc.who.int/puplications/2006 /9241594934_eng.pdf.

3. Dòria M, Rosado V, Pacheco LR, Hernández $\mathrm{M}$, Betriu A, Valls $\mathrm{J}$, Franch-Nadal J, Fernández E, and Mauricio D..Prevalence of Diabetic Foot Disease in Patients with Diabetes Mellitus under Renal Replacement Therapy in Lleida, Spain. Biomed Res Int 2016;2016:1-17.

4. Lavery L, Higgins $K$, Lanctot D. Preventing Diabetic Foot Ulcer Recurrence in High-Risk Patients. Diabetes Care 2007, 1: 14-20.

5. Gordois A, Scuffham P, Shearer A, Oglesby A, Tobian JA. The health care costs of diabetic peripheral neuropathy in the US. Diabetes Care. 2003;26: 17901795.

6. Alibasic E, Ramic E, Alic A .Prevention of diabetes in family medicine. Mater Sociomed 2013; 25: 80-82.

7. National Egyptian Guidelines for Family Physicians .Foot Care in Diabetic People. MOHP2004; 5:16-16.

8. Alibasic $\mathbf{E}$, TuzlakA, Ljuca $\mathbf{F}$, Alibasic E and Ramic E .Diabetic Foot Evaluation in Family Medicine. J Diabetes Metab2013; 6:600.

9. El-Gilany A, El-Wehady A and ElWasify M .Updating and validation of the socioeconomic status scale for health research in Egypt. EMHJ 2012 ;18 (9) .

10. James PA, Oparil S, Carter BL, Cushman WC, Dennison-Himmelfarb C, et al. evidence-based guideline for the management of high blood pressure in adults: report from the pane 1 members appointed to the Eighth Joint National Committee (JNC 8). JAMA 2014;311:507520 .

11. American Diabetes Association. Diagnosis and Classification of Diabetes Mellitus. Diabetes Care 2014 ;37: 81-90.

12. Simon L, Albright A, Belman M. Risk and Protective Factors Associated With Screening for Complications of Diabetes in a Health Maintenance Organization Setting. Diabetes Care 1999; 22: 208-212. 13. Al-Maskari F, El-Sadig M. Prevalence of risk factors for diabetic foot complications. BMC Family Practice 2007; 8: 59.

14. Nehring P, Mrozikiewicz-Rakowska B, Krzyżewska M, Sobczyk-Kopcioł A, Płoski R, Broda G and Karnafel W. Diabetic foot risk factors in type 2 diabetes patients: a cross-sectional case control study . Journal of Diabetes \& Metabolic Disorders $2014 ; 13: 79$.

15. Jayesh GB , Dinesh S, Nainesh PB, Uday RS, Salil P. A study of socio demographic and clinical profile of cases of diabetic foot . national journal of medical research $2012 ; 2(3): 279-281$.

16. Jbour AS, Jarrah NS, Radaideh AM. Prevalence and predictors of diabetic foot syndrome in type 2 diabetes mellitus in Jordan. Saudi Med J 2003; 24:761-764.

17. Abu

Obaidhttp://article.sapub.org/10.5923.j.diabe tes.20150401.01.html - Aff1 H A, Eljed A . Risk Factors for the Development of Diabetic Foot Ulcers in Gaza Strip: A Case-Control Study . International Journal of Diabetes Research2015; 4(1):1-6. 
18. Ul-muqim R, Griffin S, Ahmed. Evaluation and Management of diabetic foot according to Wagner classification: A study of 100 cases. J Ayub Medical College 2003;15(3): 39-42.

19. Al-Rubeaan Kh, Al Derwish M, Ouizi S, Youssef AM, Subhani SN. Diabetic Foot Complications and Their RiskFactors from a Large Retrospective Cohort Study. Plos One 2015; 10 (15):1-17.

20. Peters EJD, Lavery LA, Armstrong DG. Diabetic lower extremity infection influence of physical psychological and social factors. J Diab Complicat 2005;19:107-112.

21. Nather A, Siok Bee C, Keng Lin W, Qi Odelia KS, Yiong Huak C, Xinyi L, et al. Socioeconomic profile of diabetic patients with and without foot problems. Diabet Foot Ankle. 2010;1:1-5.

22. Balla S, Ahmed A, Alhassan S. Factors associated with diabetic septic foot among patients attending the diabetic septic foot unit in the military hospital, Khartoum State, Sudan. Saudi Journal of Medicine and Medical Sciences, 2013;1(2): 98-102.

23. Desalu O, Salawu F, Jimoh A, Adekoya A. Diabetic foot care: Selfreported knowledge and practice among patient attending three tertiary hospital in Nigeria. Ghana Medical Journal 2011;45(2): 60-65.

24. Hassan M, Mohamed A. Associated risk factors and management of chronic diabetic foot ulcers exceeding 6 months' duration. Diabetic Foot and Ankle, 2012;3: 10 .

25. Selby JV, Zhang D. Risk factors for lower extremity amputation in persons with diabetes. Diabetes Care 1995; 18:509516.

26. Lehto S, Ronnemaa R, Pyorala K. Risk factors predicting lower extremity amputations in patients with NIDDM. Diabetes Care 1996; 19:607-612
27. Shailesh K, Shahi M, Ashok K, Sushil K, Surya KS, Gupta, SK, Singh TB. Prevalence of diabetic foot ulcer and associated risk factors in diabetic patients from North India. The Journal of Diabetic Foot Complications, 2012; 4(3): 83-91.

28. Sima AAF, Kamiya H. Diabetic neuropathy differs in type 1 and type 2 diabetes. Ann N Y Acad Sci. 2006;1084: 235-249.

29. Hajieh S, Leila Y, Seyyed L. Risk assessment of patients with diabetes for foot ulcers according to risk classification consensus of international working group on diabetic foot (IWGDF). Pak J Med Sci 2013;29(3):730-734.

30. Moss SE, Klein R, Klein BE. The prevalence and incidence of lower extremity amputation in a diabetic population. Arch Intern Med. 1992;152: 610-616.

31. Lavery LA, Armstrong DG, Vela SA, Quebedeaux TL, Fleischli JG. Practical criteria for screening patients at high risk for diabetic foot ulceration. Arch Intern Med. 1998;158: 157-162.

32. Alex R, Ratnaraj B, Winston B, Nathaniel D, Devakiruba S, Samuel C, John J and Mohan VR. Risk Factors for Foot Ulcers in Patients with Diabetes Mellitus - A Short Report from Vellore, South India.Indian J Community Med. 2010; 35(1): 183-185.

33. Ndip A., Rutter M. K., Vileikyte L., et al. Dialysis treatment is an independent risk factor for foot ulceration in patients with diabetes and stage 4 or 5 chronic kidney disease. Diabetes Care. 2010;33(8):1811-1816.

34. Kaminski M., Frescos N., Tucker S. Prevalence of risk factors for foot ulceration in patients with end-stage renal disease on haemodialysis. Internal Medicine Journal. 2012;42(6):e120-e128. 35. Jones N. J., Chess J., Cawley S., Phillips A. O., Riley S. G. Prevalence of 
risk factors for foot ulceration in a general haemodialysis population. International Wound Journal. 2013;10(6):683-688.

36. Prompers L., Schaper N., Apelqvist J., et al. Prediction of outcome in individuals with diabetic foot ulcers: focus on the differences between individuals with and without peripheral arterial disease. The EURODIALE study. Diabetologia. 2008;51(5):747-755.

37. Ndip A., Lavery L. A., Lafontaine J., et al. High levels of foot ulceration and amputation risk in a multiracial cohort of diabetic patients on dialysis therapy. Diabetes Care. 2010;33(4):878-880

38. Bruun C, Siersma V, Guassora AD, Holstein $\mathrm{P}$, de Fine Olivarius $\mathrm{N}$. Amputations and foot ulcers in patients newly diagnosed with type 2 diabetes mellitus and observed for 19 years. The role of age, gender and co-morbidity. Diabet Med. 2013;30: 964-972.

39. Abolfotouh MA, Alfaifi SA, AlGannas AS. Risk factors of diabetic foot in central Saudi Arabia. Saudi Med J. 2011;32: 708-713 Abolfotouh MA, Alfaifi SA, Al-Gannas AS. Risk factors of diabetic foot in central Saudi Arabia. Saudi Med J. 2011;32: 708-713.

40. Lipsky BA, Berendt AR, Deery HG, Embil JM, Joseph WS, Karchmer AW, et al. Diagnosis and treatment of diabetic foot infections. Clin Infect Dis 2004;39:885910.

41. Dehghan A, Hoek M, Sijbrands E: Risk of Type 2 Diabetes Attributable to CReactive Protein and Other Risk Factors. Diabetes Care 2007, 30: 2695-2699.

42. Al Kafrawy NA, Mustafa EA, Dawood AA, Ebaid OM, Zidane OM . Study of risk factors of diabetic foot ulcers.MMJ 2014; 27 (1) :28-34.

43. Liaofang $\mathrm{Wu}$, Qian Hou, Qiuhong Zhou, Fang Peng. Prevalence of risk factors for diabetic foot complications in a Chinese tertiary hospital. Int J Clin Exp Med 2015;8(3):3785-3792.

44. Andrea L, Christman E, Selvin D. Hemoglobin A1c is a Predictor of Healing Rate In Diabetic Wounds. J Invest Dermatol., 2012:131(10): 2121-2127.

45. Meidani M, Khorvash F, Mohammad Reza. The relationship between controlling $\mathrm{HbA} 1 \mathrm{C}$ and infected diabetic foot ulcer. Journal of Isfahan Medical School, 2012;30(175): 1 .

46. Akbar N, Bilal N. The sweet foot: Relation of glycemic control with diabetic foot lesions. International Journal of Pathology, 2004;2(2):90-93. 